\title{
Vulnerability of Selected Soils in the Different Rainfall Areas to Degradation and Excessive Leaching after Winery Wastewater Application
}

\author{
A.R. Mulidzi ${ }^{1 *}$, C.E. Clarke², P.A. Myburgh ${ }^{1}$ \\ ${ }^{1}$ ARC Infruitec-Nietvoorbij, Private Bag X5026, 7599, Stellenbosch, South Africa ${ }^{2}$ Department of Soil Science, Stellenbosch \\ University, Private Bag X1, Matieland 7602, South Africa.
}

Submitted for publication: November 2019

Accepted for publication: March 2020

Key words: Chemical oxygen demand, Rainfall simulation, Water quality, Winery wastewater

\begin{abstract}
A pot trial was conducted to assess the effect of simulated rainfall on six soils with different textures, irrigated with winery wastewater diluted to a chemical oxygen demand (COD) level of $3000 \mathrm{mg} / \mathrm{L}$ over one simulated irrigation season. Thereafter, simulated winter rainfall was applied to the pots. The rainfall was simulated according to the long term averages of the regions where the soils originated. Leaching of cations, particularly $\mathrm{K}^{+}$and $\mathrm{Na}^{+}$occurred only from four of the six soils when winter rainfall was simulated. In one of the sandy soils, the simulated rainfall was too low to allow leaching. In another soil, high clay content of $35 \%$ in combination with low rainfall prevented leaching. In three soils that received the same amount of rainfall, more cations leached from the duplex sandy soil compared to the two other soils. These trends indicated that leaching of cations was a function of soil texture and rainfall. The study showed that in regions with low rainfall, irrigation with winery wastewater would lead to the accumulation of cations thereby increasing soil salinity. The study confirmed that for sustainable use of winery wastewater irrigation in agriculture, different soil types will require individual management in order to avoid or minimize the negative environmental impact on natural resources by wastewater irrigation.
\end{abstract}

\section{INTRODUCTION}

Studies regarding climate change in the wine growing regions of the Western Cape Province have shown sharp increases in air temperature, whereas rainfall is expected to decline, or to be differently distributed during the rainy season (Vink et al., 2012). In 2017, the Western Cape experienced the worst drought in a decade and this will have a lasting effect on agricultural production in future (Mulidzi et al., 2019).

The average annual grape production in South Africa was 1.33 million tonnes from 2010 until 2012 and wineries generate large volumes of poor quality wastewater, particularly during harvest (Howell \& Myburgh, 2018). It is estimated that $c .3$ to $5 \mathrm{~m}^{3}$ of winery wastewater with high organic load and variable salinity and nutrient levels is produced per tonne of grapes crushed (Howell et al., 2018). Most winery wastewater is currently irrigated onto pastures, but because of the drought and climate changes, the idea of using winery wastewater to irrigate vineyards has been encouraged (Mulidzi et al., 2019). Winter rainfall after winery wastewater irrigation may lead to the leaching of nutrients to the groundwater. Changes in soil structure due to wastewater irrigation depend on the quality of wastewater, i.e. salinity levels, organic matter content, and the amount of total suspended solids (Muller et al., 2007). The rate and amount of pollutants from winery wastewater reaching groundwater resources depend on several factors such as: sorption, degradation, chemical properties of the wastewater, soil characteristics, environmental conditions, rainfall and water management practices (Mulidzi et al., 2018). Salinesodic irrigation water in low rainfall and high evaporation areas will increase soil sodicity. Furthermore, a major side effect associated with wastewater irrigation is the potentially irreversible deterioration of the groundwater quality (Mulidzi et al., 2016). The electric conductivity (EC) of Fluvisol soils decreased as a result of leaching of salts by the AutumnSpring rainfall (Mulidzi et al., 2018). However, due to high cation exchange capacity (CEC) and high water retention

\footnotetext{
${ }^{1}$ The Fruit, Vine and Wine Institute of the Agricultural Research Council

*Corresponding author: E-mail address: mulidzir@arc.agric.za

Acknowledgements: The Water Research Commission for initiating and funding the project. Winetech, THRIP (TP1208066038) and the Agricultural Research Council for co-funding. Staff of Soil and Water Science at ARC Infruitec-Nietvoorbij for technical support, and in particular Mr Francois Baron for his dedicated effort. Any opinions, findings and conclusions or recommendations expressed in any publication generated through THRIP-supported research, are those of the authors and therefore the NRF/THRIP will not accept any liability in that regard
} 
capacity, the soils still retained high levels of $\mathrm{Na}^{+}$. Winter rainfall on soils irrigated with winery wastewater will lead to the reduction of soil electrolyte concentrations regardless of soil type. Low rainfall areas are likely to experience less soil structural hazard, which is linked to high exchangeable monovalent cation concentrations while high rainfall areas will experience more soil structural hazard (Suarez et al., 2008).

The objective of the study was to investigate the effect of simulated winter rainfall on leaching of basic cations in soils irrigated with diluted winery wastewater.

\section{MATERIALS AND METHODS}

\section{Soils used}

Six pedogenetically different soils commonly found in the Western Cape province of South Africa were included in the study (Table 1). The taxonomic classification of the soils is given according to the South African soil classification system (Soil Classification Work Group, 1991) as well as World Reference Base (IUSS Working Group WRB, 2014). For the purpose of this article, soils will be referred to as Rawsonville sand, Lutzville sand, Stellenbosch shale, Stellenbosch granite, Stellenbosch sand and Robertson clay. The soil was packed into PVC pots to a specific predetermined bulk density as described by Mulidzi et al, (2016).

\section{Application of water to the soils}

For the control treatment, the soils were irrigated with water abstracted from the Holsloot River near Rawsonville in the Breede River valley. Water used for the wastewater treatment was collected from the wastewater pit at a winery near Rawsonville. The winery wastewater was then diluted to a chemical oxygen demand (COD) level of $3000 \mathrm{mg} / \mathrm{L}$. Six irrigations were applied over one simulated season. It was estimated that six is the number of irrigations a microsprinkler irrigated vineyard would require during the harvest period, i.e. when the highest volumes of wastewater are produced. Irrigation was applied when $c$. $50 \%$ of the water had evaporated (Fig. 1). The latter was considered to be the recommended level of depletion for vineyards to obtain a balance between yield and wine quality.

After one simulated irrigation season, simulated winter rainfall was applied to all treatments. Since the pot experiment was carried out in summer, there was no source of uncontaminated rainwater available. It was decided not to use distilled or de-ionized water for the rainfall simulations, since using distilled water changes the ionic balances and may flocculate or disperse the clay in the soil (Amezketa et al., 2004). Soil water contains solutes which are in balance with ions on exchange sites of the clay. Based on the forgoing, "rainwater" for the study was also abstracted from the Holsloot River, i.e. from a natural source where contamination is least expected. The amount of rainfall applied to each soil was based on the long term mean winter rainfall for each of the different regions where the soil was collected. During, and after each irrigation, as well as during and after each simulated rainfall day, the leachate was collected and pooled and no statistical analysis was performed on the analysis.

The total volume of leachate for each soil was recorded at the end of the simulated rainfall period. The chemical status of the leachate from each soil was determined in samples collected from the pooled leachate.

\section{Water sampling and analyses}

Water samples were collected from the river water and wastewater tanks prior to each irrigation (Table 2). The $\mathrm{pH}$, electrical conductivity (EC), $\mathrm{Na}^{+}, \mathrm{K}^{+}, \mathrm{Ca}^{2+}, \mathrm{Mg}^{2+}, \mathrm{Fe}, \mathrm{Cl}^{-}$, $\mathrm{HCO}_{3}^{-}, \mathrm{SO}_{4}^{2-}, \mathrm{B}^{-}$and $\mathrm{COD}$ were determined at a commercial laboratory (BEMLAB, Strand). Details of the analytical procedures were described previously by Mulidzi et al. (2015).

\section{Soil sampling and analyses}

After six irrigations, i.e. one simulated winery wastewater irrigation season, soil samples were collected from the 0 to $19 \mathrm{~cm}$ soil layer. Soil sampling was again carried out after the simulated winter rainfall had been applied. All analyses were carried out at a commercial laboratory (BEMLAB, Strand). Details of the analytical procedures were described previously by Mulidzi et al. (2016).

\section{Soil characterization}

The six selected soils represent soils dominant in three of the main South African wine producing regions. It was expected that the effect of winter rainfall after winery wastewater irrigation would differ between different soils. The results of the chemical properties of the six soils are presented in Table 3. The $\mathrm{pH}$ of the six soils ranged between 4.2 and 6.6, whereas the electrical conductivity of the saturated extract $\left(\mathrm{EC}_{\mathrm{e}}\right)$ ranged between 20 and $70 \mathrm{mS} / \mathrm{m}$. The cation exchange capacity (CEC) ranged between 2.9 and $8.3 \mathrm{cmol}_{\mathrm{c}} \cdot \mathrm{kg}^{-1}$ (Table 3). The Robertson soil had the highest clay content, i.e. $35 \%$, whereas the Lutzville sand contained only $0.4 \%$ clay (Table 4).

\section{Composition and amount of simulated winter rainfall applied}

The overall average chemical composition of the Holsloot river water used to simulate winter rainfall was within the acceptable range for irrigation water (Table 2). The $\mathrm{pH}$ levels were below the recommended $\mathrm{pH}$ for irrigation water ranging from 6.5 to 8.4 (DWAF, 1996). The amount of rainfall applied was calculated from the long term average winter rainfall in the region where each soil was collected (Table 5). Rawsonville soils received the highest amount of rainfall per day $(13.8 \mathrm{~mm})$ followed by the three soils from Stellenbosch $(9.3 \mathrm{~mm})$, while the Robertson and Lutzville soils received the least rainfall ( $4.5 \& 3.8 \mathrm{~mm}$, respectively) (Table 5).

\section{Statistical procedures}

The study was carried out under a $20 \mathrm{~m} \times 40 \mathrm{~m}$ translucent fiberglass rain shelter at ARC Infruitec-Nietvoorbij near Stellenbosch. Each soil/water treatment was replicated three times in a complete randomized design, i.e. 6 (soil) $\mathrm{x} 2$ (water) x 3 (replicates). The six soils were randomly allocated within each block. The samples from 3 replicates were pooled together. The treatment design was a split-plot. Analyses of variance were performed separately for each season using 
TABLE 1

Origin, soil classification, as well as general descriptions and co-ordinates for the six soils used.

\begin{tabular}{|c|c|c|c|c|}
\hline \multirow[b]{2}{*}{ Origin } & \multicolumn{2}{|c|}{ Classification } & \multirow[b]{2}{*}{ General description } & \multirow[b]{2}{*}{ Co-ordinates } \\
\hline & $\mathbf{S A}^{1}$ & $\mathbf{W R B}^{2}$ & & \\
\hline Rawsonville & Longlands & Gleyic, albic,Arenosol & Rawsonville sand & $-33.4137 .7^{\circ} 19.1920 .3^{\circ}$ \\
\hline Lutzville & Garies & Eutric, petric, Durisol & Lutzville sand & $-31.5589 .1^{\circ} 18.3531 .2^{\circ}$ \\
\hline Stellenbosch & Oakleaf & Chromic, Acrisol & Stellenbosch shale & $-33.550 .28^{\circ} 18.520 .69^{\circ}$ \\
\hline Stellenbosch & Cartref & Albic, leptic, Acrisol & Stellenbosch granite & $-33.5439 .9^{\circ} 18.5216 .6^{\circ}$ \\
\hline Stellenbosch & Kroonstad & Gleyic, albic,Planosol & Stellenbosch sand & $-33.4958 .6^{\circ} 18.4759 .9^{\circ}$ \\
\hline Robertson & Valsrivier & Chromic, Lixisol & Robertson clay & $-33.4923 .6^{\circ} 19.5236 .0^{\circ}$ \\
\hline
\end{tabular}

${ }^{1}$ Soil Classification Work Group, 1991

${ }^{2}$ World Reference Base (IUSS Working Group WRB), 2014
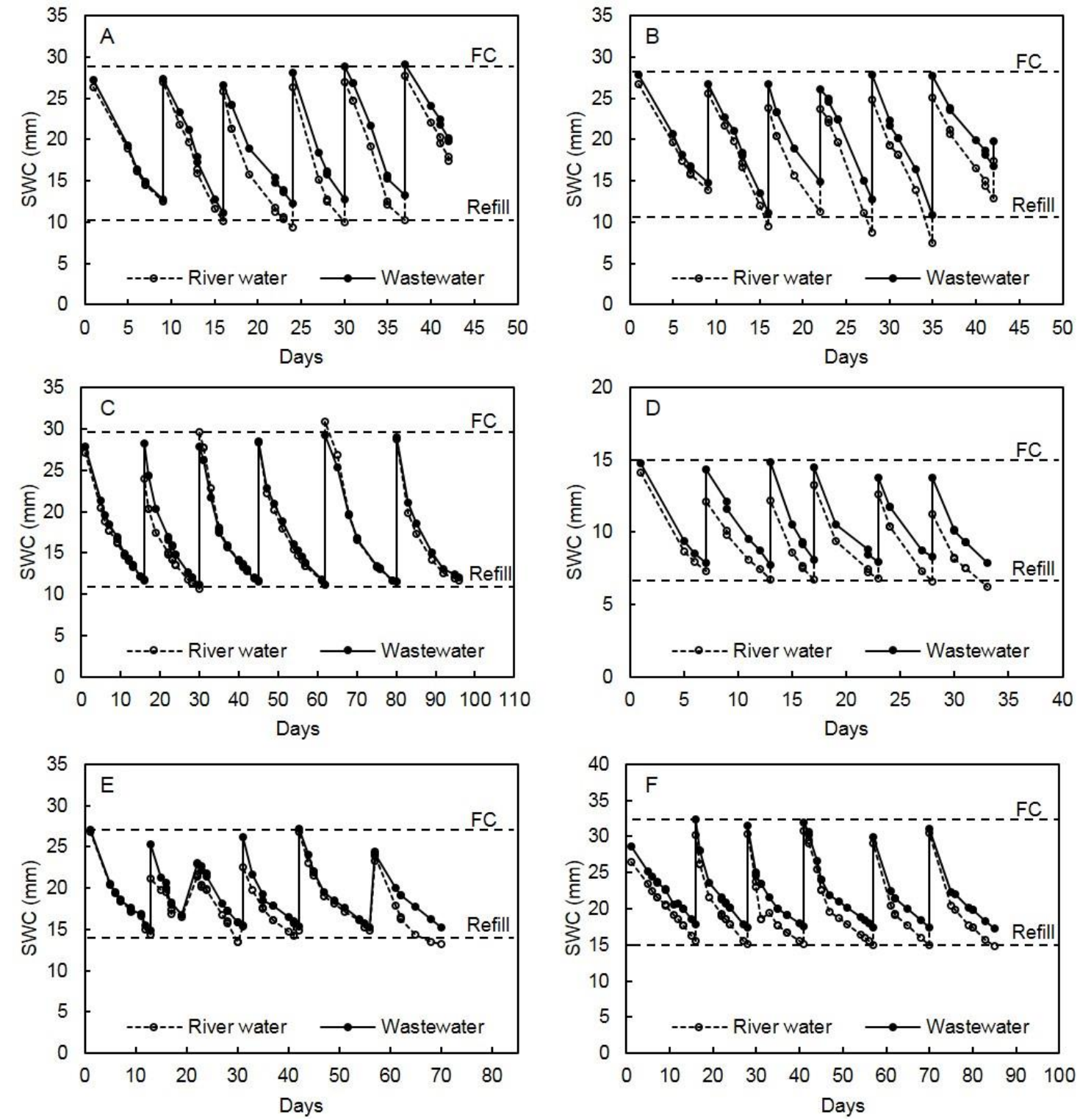

FIGURE 1

Variation in soil water content (SWC) in (A) Rawsonville sand, (B) Lutzville sand, (C) Stellenbosch shale, (D) Stellenbosch granite, (E) Stellenbosch sand and (F) Robertson sandy loam soils where river water and diluted winery wastewater were applied to simulate one season's irrigation. The first irrigations were applied on 02-01-2013. Dashed horizontal lines indicate field capacity (FC) and the refill point. 
TABLE 2

Chemical composition of raw water abstracted from the Holsloot River near Rawsonville used for simulating winter rainfall and water obtained from the Stellenbosch municipality.

\begin{tabular}{|c|c|c|}
\hline Variable & Raw water & Municipal water \\
\hline $\mathrm{pH}$ & 6.1 & 7.2 \\
\hline $\mathrm{EC}^{1}(\mathrm{mS} / \mathrm{m})$ & 18.0 & 11.2 \\
\hline $\mathrm{Na}^{+}(\mathrm{mg} / \mathrm{L})$ & 10.0 & 9.3 \\
\hline $\mathrm{K}^{+}(\mathrm{mg} / \mathrm{L})$ & 1.1 & 1.4 \\
\hline $\mathrm{Ca}^{2+}(\mathrm{mg} / \mathrm{L})$ & 7.4 & 8.3 \\
\hline $\mathrm{Mg}^{2+}(\mathrm{mg} / \mathrm{L})$ & 3.5 & 2.1 \\
\hline SAR & 0.76 & 0.75 \\
\hline $\mathrm{Fe}^{2+}(\mathrm{mg} / \mathrm{L})$ & 0.04 & 0.1 \\
\hline $\mathrm{B}^{3+}(\mathrm{mg} / \mathrm{L})$ & 0.03 & 0.01 \\
\hline $\mathrm{Mn}^{2+}(\mathrm{mg} / \mathrm{L})$ & 0.04 & 0.01 \\
\hline $\mathrm{Zn}^{2+}(\mathrm{mg} / \mathrm{L})$ & 0.83 & 0.19 \\
\hline $\mathrm{P}(\mathrm{mg} / \mathrm{L})$ & 0.01 & 0.04 \\
\hline $\mathrm{NH}_{4}^{+}-\mathrm{N}(\mathrm{mg} / \mathrm{L})$ & 2.47 & 0.59 \\
\hline $\mathrm{NO}_{3}^{-}-\mathrm{N}(\mathrm{mg} / \mathrm{L})$ & 0.95 & 0.11 \\
\hline $\mathrm{Cl}^{-}(\mathrm{mg} / \mathrm{L})$ & 89.8 & 21.2 \\
\hline $\mathrm{HCO}_{3}^{-}(\mathrm{mg} / \mathrm{L})$ & 15.3 & 26.7 \\
\hline $\mathrm{SO}_{4}^{2-}(\mathrm{mg} / \mathrm{L})$ & 6.1 & 3.2 \\
\hline $\mathrm{TDS}^{2}(\mathrm{mg} / \mathrm{L})$ & 75.1 & 45 \\
\hline $\mathrm{COD}^{3}(\mathrm{mg} / \mathrm{L})$ & 56 & 47 \\
\hline
\end{tabular}

${ }^{1}$ Electrical conductivity

${ }^{2}$ Total dissolved solids

${ }^{3}$ Chemical oxygen demand

TABLE 3

Chemical properties of the six soils before application of the river water and diluted winery wastewater irrigations.

\begin{tabular}{|c|c|c|c|c|c|c|}
\hline Variable & $\begin{array}{c}\text { Rawsonville } \\
\text { sand }\end{array}$ & $\begin{array}{c}\text { Lutzville } \\
\text { sand }\end{array}$ & $\begin{array}{c}\text { Stellenbosch } \\
\text { shale }\end{array}$ & $\begin{array}{c}\text { Stellenbosch } \\
\text { granite }\end{array}$ & $\begin{array}{c}\text { Stellenbosch } \\
\text { sand }\end{array}$ & $\begin{array}{c}\text { Robertson } \\
\text { clay }\end{array}$ \\
\hline $\mathrm{pH}$ & 5.8 & 6.5 & 4.2 & 4.3 & 4.3 & 6.6 \\
\hline $\mathrm{EC}_{\mathrm{e}}^{1}(\mathrm{mS} / \mathrm{m})$ & 30 & 20 & 30 & 40 & 20 & 70 \\
\hline Bray II P (mg/kg) & 227 & 21 & 8 & 11 & 28 & 102 \\
\hline BrayII K (mg/kg) & 66 & 240 & 95 & 99 & 206 & 702 \\
\hline Organic C (\%) & 0.8 & 0.2 & 1.5 & 1.3 & 0.9 & 0.6 \\
\hline $\mathrm{K}^{+}{ }_{\text {extr }}\left(\mathrm{cmol}_{\mathrm{c}} \cdot \mathrm{kg}^{-1}\right)$ & 0.17 & 0.61 & 0.24 & 0.25 & 0.53 & 1.79 \\
\hline $\mathrm{Na}_{\text {extr }}^{+}\left(\mathrm{cmol}_{\mathrm{c}} \cdot \mathrm{kg}^{-1}\right)$ & 0.01 & 0.05 & 0.06 & 0.05 & 0.02 & 0.37 \\
\hline $\mathrm{Ca}^{2+}{ }_{\text {extr }}\left(\mathrm{cmol}_{\mathrm{c}} \cdot \mathrm{kg}^{-1}\right)$ & 2.79 & 3.22 & 1.64 & 1.21 & 0.7 & 9.17 \\
\hline $\mathrm{Mg}^{2+}{ }_{\text {extr }}\left(\mathrm{cmol}_{\mathrm{c}} \cdot \mathrm{kg}^{-1}\right)$ & 0.95 & 0.8 & 0.61 & 0.51 & 0.22 & 3.02 \\
\hline $\mathrm{CEC}^{2}\left(\mathrm{cmol}_{\mathrm{c}} \cdot \mathrm{kg}^{-1}\right)$ & 3.9 & 3.4 & 4.3 & 3.6 & 2.9 & 8.3 \\
\hline
\end{tabular}

${ }^{1}$ Electrical conductivity

${ }^{2}$ Cation exchange capacity 
TABLE 4

Particle size distribution and textural class of the six soils used in the study.

\begin{tabular}{lcccccc}
\hline $\begin{array}{l}\text { Particle size \& } \\
\text { textural class }\end{array}$ & $\begin{array}{c}\text { Rawsonville } \\
\text { sand }\end{array}$ & $\begin{array}{c}\text { Lutzville } \\
\text { sand }\end{array}$ & $\begin{array}{c}\text { Stellenbosch } \\
\text { shale }\end{array}$ & $\begin{array}{c}\text { Stellenbosch } \\
\text { granite }\end{array}$ & $\begin{array}{c}\text { Stellenbosch } \\
\text { sand }\end{array}$ & $\begin{array}{c}\text { Robertson } \\
\text { clay }\end{array}$ \\
\hline $\begin{array}{l}\text { Clay } \\
(<0.002 \mathrm{~mm})\end{array}$ & $\mathbf{3 . 3}$ & $\mathbf{0 . 4}$ & $\mathbf{2 0}$ & $\mathbf{1 3}$ & $\mathbf{7}$ & $\mathbf{3 5}$ \\
$\begin{array}{l}\text { Silt } \\
(0.002-0.02 \mathrm{~mm})\end{array}$ & $\mathbf{1}$ & $\mathbf{1}$ & $\mathbf{1 3}$ & $\mathbf{1 7}$ & $\mathbf{6}$ & $\mathbf{2 0}$ \\
$\begin{array}{l}\text { Fine sand } \\
(0.02-0.2 \mathrm{~mm})\end{array}$ & $\mathbf{6 0}$ & $\mathbf{6 9}$ & $\mathbf{5 0}$ & $\mathbf{3 3}$ & $\mathbf{3 9}$ & $\mathbf{3 5}$ \\
$\begin{array}{l}\text { Medium sand } \\
(0.2-0.5 \mathrm{~mm})\end{array}$ & $\mathbf{2 9}$ & $\mathbf{2 6}$ & $\mathbf{5}$ & $\mathbf{3}$ & $\mathbf{2 6}$ & $\mathbf{7}$ \\
$\begin{array}{l}\text { Coarse sand } \\
(0.5-2 \mathrm{~mm})\end{array}$ & $\mathbf{8}$ & $\mathbf{2}$ & $\mathbf{1 2}$ & $\mathbf{3 5}$ & $\mathbf{2 2}$ & $\mathbf{3}$ \\
\hline Textural class & Sand & Sand & $\begin{array}{c}\text { Sandy clay } \\
\text { loam }\end{array}$ & Sandy loam & Sand & Clay loam \\
\hline
\end{tabular}

TABLE 5

Mean number of rainfall days, interval between rainfall days and amount of water per rainfall day during winter, i.e. form May until September, at the four sampling localities, as well as the volume of water applied per pot to simulate the rainfall.

\begin{tabular}{lcccc}
\hline Soils & $\begin{array}{c}\text { Number of } \\
\text { rainfall days }\end{array}$ & $\begin{array}{c}\text { Interval between } \\
\text { rainfall days (days) }\end{array}$ & \multicolumn{2}{c}{ Amount per rainfall day } \\
\cline { 4 - 5 } (mm/day) & (mL/pot) \\
\hline Rawsonville sand & 41 & 4 & 13.8 & 244 \\
Lutzville sand & 25 & 6 & 3.7 & 67 \\
Stellenbosch shale & 50 & 3 & 9.3 & 164 \\
Stellenbosch granite & 50 & 3 & 9.3 & 164 \\
Stellenbosch sand & 50 & 3 & 9.3 & 164 \\
Robertson clay & 34 & 5 & 4.5 & 80 \\
\hline
\end{tabular}

SAS version 9.2 (SAS, 2008). The Shapiro-Wilk test was performed to test for non-normality (Shapiro \& Wilk, 1965). Student's t-least significant difference (LSD) was calculated at the $5 \%$ significance level to facilitate comparison between treatment means (Ott, 1998). STATGRAPHICS ${ }^{\circledR}$ was used to calculate the multiple linear regression equations.

\section{RESULTS AND DISCUSSION}

Chemical composition of the irrigation waters

The chemical composition of the river water was within the acceptable range for irrigation water (Table 6). The average water $\mathrm{pH}$ for six irrigations was 7.2, which is lower than the 8.4 which is the maximum threshold for irrigation (DWAF, 1996). The average EC value was $21 \mathrm{mS} / \mathrm{m}$, which was well below the $75 \mathrm{mS} / \mathrm{m}$ salinity threshold value for grapevine irrigation (Myburgh, 2012). The average COD was $44.8 \mathrm{mg} / \mathrm{L}$ (Table 6), which is in line with normal drinking water. The overall $\mathrm{Na}^{+}$and $\mathrm{K}^{+}$levels were very low. With the exception of $\mathrm{pH}$, winery wastewater chemical parameters were higher than those of the river water. The most noticeable elements and properties that were higher in the wastewater were $\mathrm{K}^{+}$, $\mathrm{HCO}_{3}^{-}, \mathrm{EC}$, TDS and COD (Table 7). Although the average $\mathrm{HCO}_{3}^{-}$in the winery wastewater was high, levels were only high for the first three irrigations. Thereafter $\mathrm{HCO}_{3}^{-}$levels dropped to almost zero in the last three irrigations. This could be attributed to the winery using different detergents during the latter period.

\section{Comparison of the chemical status of the river water and} actual rainfall

The river water used in the study contained substantially more basic cations while other studies have shown that rainwater collected at Citrusdal and Cape Town had less basic cations (Fig. 2). In contrast, rainwater harvested at Kleinmond tended to contain more $\mathrm{Na}^{+}, \mathrm{K}^{+}$, and $\mathrm{Ca}^{2+}$ than the water abstracted from the Holsloot River. This suggested that the rainwater at Kleinmond was probably contaminated in the harvesting process. The cations in the river water was comparable to the water obtained from the Stellenbosch municipality (Fig. 2). It must be noted the level of $\mathrm{Na}^{+}$were higher compared to the other cations in all the waters. The $\mathrm{pH}$ of the river and municipal water tended to be slightly higher than that of the rainwater. The SAR in all the waters were relatively low, i.e. less than 1.5 (Fig. 3). 
TABLE 6

Variation in the river water quality used for irrigation of six different soils in a pot experiment during a simulated winery wastewater irrigation season.

\begin{tabular}{|c|c|c|c|c|c|c|c|}
\hline \multirow{2}{*}{$\begin{array}{l}\text { Water quality } \\
\text { variable }\end{array}$} & \multicolumn{7}{|c|}{ Sampling date } \\
\hline & 03-01-2013 & 11-01-2013 & 18-01-2013 & 24-01-2013 & 06-02-2013 & 13-02-2013 & Average \\
\hline $\mathrm{pH}$ & 7.6 & 7.8 & 7.6 & 6.8 & 7 & 6.2 & 7.2 \\
\hline $\mathrm{EC}^{1}(\mathrm{mS} / \mathrm{m})$ & 44 & 17 & 9 & 18.7 & 18.9 & 18.1 & 21.0 \\
\hline $\mathrm{Na}^{+}(\mathrm{mg} / \mathrm{L})$ & 53.9 & 11.6 & 12.6 & 12.9 & 42.4 & 13.5 & 24.5 \\
\hline $\mathrm{K}^{+}(\mathrm{mg} / \mathrm{L})$ & 5.6 & 3.4 & 2.6 & 2.7 & 3.1 & 2.5 & 3.3 \\
\hline $\mathrm{Ca}^{2+}(\mathrm{mg} / \mathrm{L})$ & 21.2 & 14.2 & 11.9 & 11.5 & 10.3 & 8.9 & 13.0 \\
\hline $\mathrm{Mg}^{2+}(\mathrm{mg} / \mathrm{L})$ & 11.5 & 5 & 5 & 5.2 & 8.3 & 5.5 & 6.8 \\
\hline $\mathrm{SAR}^{2}$ & 2.4 & 0.7 & 0.8 & 0.8 & 2.4 & 0.9 & 1.3 \\
\hline $\mathrm{Fe}^{2+}(\mathrm{mg} / \mathrm{L})$ & 2.3 & 0.05 & 0.01 & 0.01 & 0 & 0 & 0.4 \\
\hline $\mathrm{B}^{3+}(\mathrm{mg} / \mathrm{L})$ & 0.01 & 0.02 & 0 & 0 & 0 & 0.02 & 0.0 \\
\hline $\mathrm{Mn}^{2+}(\mathrm{mg} / \mathrm{L})$ & 0.04 & 0.08 & 0.09 & 0.04 & 0.05 & 0.05 & 0.1 \\
\hline $\mathrm{Cu}^{2+}(\mathrm{mg} / \mathrm{L})$ & 0.03 & 0.02 & 0.01 & 0 & 0.01 & 0 & 0.0 \\
\hline $\mathrm{Zn}^{2+}(\mathrm{mg} / \mathrm{L})$ & 0.4 & 0.02 & 0.07 & 0.4 & 0.53 & 0.7 & 0.4 \\
\hline $\mathrm{P}(\mathrm{mg} / \mathrm{L})$ & 0.2 & 0.12 & 0 & 0.02 & 0 & 0.03 & 0.1 \\
\hline $\mathrm{NH}_{4}^{+}-\mathrm{N}(\mathrm{mg} / \mathrm{L})$ & 0.5 & 0.4 & 0.4 & 1.9 & 0.23 & 2.04 & 0.9 \\
\hline $\mathrm{NO}_{3}^{-}-\mathrm{N}(\mathrm{mg} / \mathrm{L})$ & 14 & 0.5 & 1.1 & 0 & 2.7 & 0.8 & 3.2 \\
\hline $\mathrm{Cl}^{-}(\mathrm{mg} / \mathrm{L})$ & 72.4 & 27.7 & 28.9 & 31 & 22.1 & 39.8 & 37.0 \\
\hline $\mathrm{HCO}_{3}^{-}(\mathrm{mg} / \mathrm{L})$ & 55.1 & 10.4 & 12.1 & 9.2 & 15.3 & 22.9 & 20.8 \\
\hline $\mathrm{SO}_{4}^{2-}(\mathrm{mg} / \mathrm{L})$ & 27.4 & 25.4 & 24.5 & 54 & 32 & 33 & 32.7 \\
\hline $\mathrm{TDS}^{3}(\mathrm{mg} / \mathrm{L})$ & 264 & 45 & 52 & 119 & 121 & 116 & 120 \\
\hline $\mathrm{COD}^{4}(\mathrm{mg} / \mathrm{L})$ & 48 & 62 & 57 & 18 & 38 & 46 & 45 \\
\hline
\end{tabular}

${ }^{1}$ Electrical conductivity

${ }^{2}$ Sodium adsorption ratio

${ }^{3}$ Total dissolved solids

${ }^{4}$ Chemical oxygen demand

TABLE 7

Quality variation of winery wastewater diluted to $3000 \mathrm{mg} / \mathrm{L}$ COD for irrigation of six different soils in a pot experiment during a simulated winery wastewater irrigation season.

\begin{tabular}{|c|c|c|c|c|c|c|c|}
\hline \multirow{2}{*}{$\begin{array}{l}\text { Water quality } \\
\text { variable }\end{array}$} & \multicolumn{7}{|c|}{ Sampling date } \\
\hline & 03-01-2013 & 11-01-2013 & 18-01-2013 & 24-01-2013 & 06-02-2013 & 13-02-2013 & Average \\
\hline $\mathrm{pH}$ & 6.1 & 6.9 & 7.9 & 4.9 & 4.1 & 3.9 & 5.6 \\
\hline $\mathrm{EC}^{1}(\mathrm{mS} / \mathrm{m})$ & 236 & 212 & 246 & 39 & 45 & 41 & 137 \\
\hline $\mathrm{Na}^{+}(\mathrm{mg} / \mathrm{L})$ & 65 & 69 & 86 & 20 & 26 & 19 & 48 \\
\hline $\mathrm{K}^{+}(\mathrm{mg} / \mathrm{L})$ & 487 & 422 & 663 & 55 & 50 & 45 & 287 \\
\hline $\mathrm{Ca}^{2+}(\mathrm{mg} / \mathrm{L})$ & 45.1 & 70.3 & 43.2 & 21.2 & 13.7 & 14.9 & 34.7 \\
\hline $\mathrm{Mg}^{2+}(\mathrm{mg} / \mathrm{L})$ & 39.1 & 44.6 & 62.4 & 10.1 & 9.5 & 9.5 & 29.2 \\
\hline $\mathrm{SAR}^{2}$ & 1.7 & 1.6 & 2.0 & 0.9 & 1.3 & 7.1 & 2.4 \\
\hline $\mathrm{Fe}^{2+}(\mathrm{mg} / \mathrm{L})$ & 4.7 & 3.5 & 1.5 & 1.9 & 4.8 & 4.01 & 3.4 \\
\hline $\mathrm{B}^{3+}(\mathrm{mg} / \mathrm{L})$ & 0.44 & 0.6 & 0.8 & 0.11 & 0 & 0.14 & 0.3 \\
\hline
\end{tabular}




\begin{tabular}{lccccccc}
\hline \multirow{2}{*}{$\begin{array}{l}\text { Water quality } \\
\text { variable }\end{array}$} & \multicolumn{7}{c}{ Sampling date } \\
\cline { 2 - 8 } & $\mathbf{0 3 - 0 1 - 2 0 1 3}$ & $\mathbf{1 1 - 0 1 - 2 0 1 3}$ & $\mathbf{1 8 - 0 1 - 2 0 1 3}$ & $\mathbf{2 4 - 0 1 - 2 0 1 3}$ & $\mathbf{0 6 - 0 2 - 2 0 1 3}$ & $\mathbf{1 3 - 0 2 - 2 0 1 3}$ & Average \\
\hline $\mathrm{Mn}^{2+}(\mathrm{mg} / \mathrm{L})$ & 0.4 & 0.7 & 0.5 & 0.2 & 0.2 & 0.16 & 0.4 \\
$\mathrm{Cu}^{2+}(\mathrm{mg} / \mathrm{L})$ & 0.03 & 0.04 & 0.2 & 0.1 & 0.1 & 0.23 & 0.1 \\
$\mathrm{Zn}^{2+}(\mathrm{mg} / \mathrm{L})$ & 0.02 & 0.11 & 0.5 & 0.5 & 0.9 & 1.39 & 0.6 \\
$\mathrm{P}(\mathrm{mg} / \mathrm{L})$ & 21.9 & 26.4 & 42.5 & 6 & 6.1 & 6.12 & 53 \\
$\mathrm{NH}_{4}{ }^{+}-\mathrm{N}(\mathrm{mg} / \mathrm{L})$ & 12 & 8.5 & 17.2 & 2.2 & 0.8 & 1 & 687 \\
$\mathrm{NO}_{3}^{-}-\mathrm{N}(\mathrm{mg} / \mathrm{L})$ & 240 & 4.9 & 0.3 & 0 & 0.8 & 1.34 & 187 \\
$\mathrm{Cl}^{-}(\mathrm{mg} / \mathrm{L})$ & 57 & 82 & 51 & 34 & 45 & 48 & 0.3 \\
$\mathrm{HCO}_{3}^{-}(\mathrm{mg} / \mathrm{L})$ & 975 & 1047 & 2102 & 0.01 & 0.1 & 0.2 & 0.4 \\
$\mathrm{SO}_{4}^{2-}(\mathrm{mg} / \mathrm{L})$ & 765 & 39 & 123 & 43 & 117 & 36 & 0.1 \\
$\mathrm{TDS}^{3}(\mathrm{mg} / \mathrm{L})$ & 1418 & 567 & 1490 & 246 & 289 & 245 & 709 \\
$\mathrm{COD}^{4}(\mathrm{mg} / \mathrm{L})$ & 3080 & 2870 & 3460 & 3540 & 3350 & 3500 & 3300 \\
\hline
\end{tabular}

${ }^{1}$ Electrical conductivity

${ }^{2}$ Sodium adsorption ratio

${ }^{3}$ Total dissolved solids

${ }^{4}$ Chemical oxygen demand

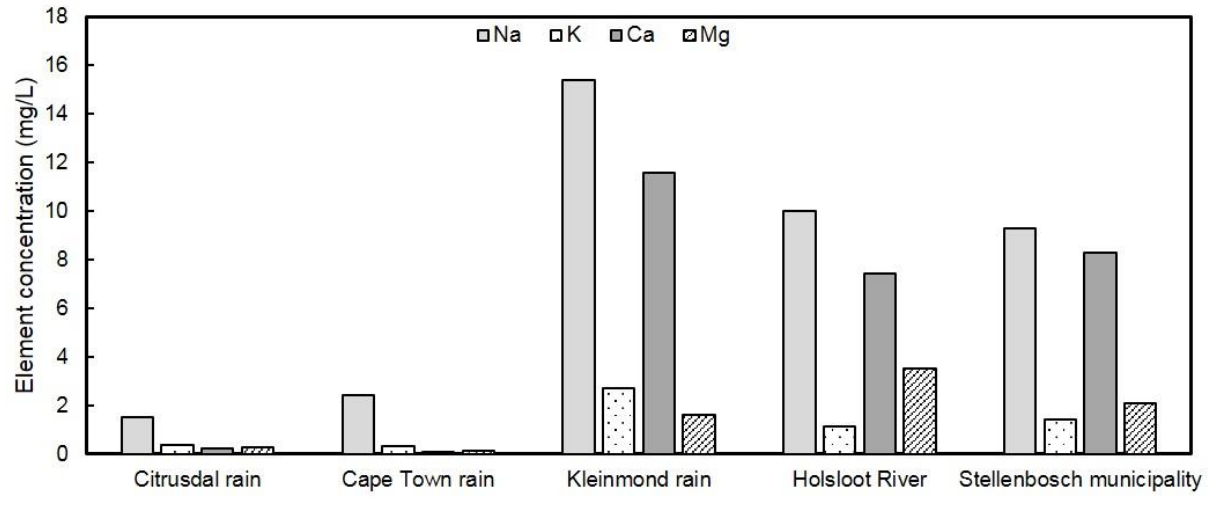

FIGURE 2

Basic cation concentration in rainwater collected at Citrusdal and Cape Town (after Soderberg, 2003) and rainwater harvested at Kleinmond (after Dobrowsky, 2014) compared to water obtained from the Holsloot River near Rawsonville and the Stellenbosch municipality, respectively.

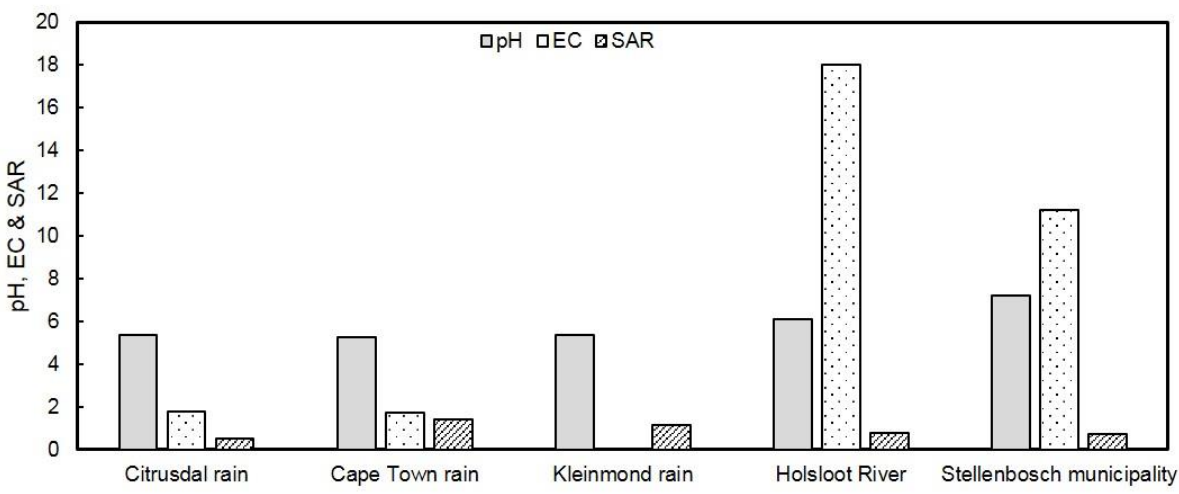

FIGURE 3

The $\mathrm{pH}$, electrical conductivity (EC) and sodium adsorption ratio (SAR) in rainwater collected at Citrusdal and Cape Town (Soderberg, 2003) and rainwater harvested at Kleinmond (Dobrowski, 2014) compared to water obtained from the Holsloot River near Rawsonville and the Stellenbosch municipality, respectively. The EC was not determined at Kleinmond. 


\section{Composition of leachate after simulated winter rainfall}

No leaching occurred in the case of the Lutzville and Robertson soils after the simulated winter rainfall had been applied. This indicated that the volumes of simulated rainfall were inadequate to leach the elements applied via wastewater nutrients from these soils. In the case of the Robertson clay, a high water holding capacity could have prevented leaching of solutes. For the soils where leaching occurred, extremely small volumes of solutes leached following a simulated rainfall event. Only $0.83 \pm 0.15,0.36 \pm 0.14,0.55 \pm 0.16$ and $0.64 \pm 0.14 \mathrm{~mL}$ were collected per rainfall event for the Rawsonville sand, Stellenbosch shale, Stellenbosch granite and Stellenbosch sand, respectively. The total leachate used for the chemical analyses amounted to 34.5, 18.6, 27.9 and $32.7 \mathrm{~mL}$, respectively, per treatment replication for the four soils. It must be noted that the same amount of rainfall was applied to the three Stellenbosch soils.

The chemical composition of the leachates varied considerably (Table 8). Although no statistical analysis was done, in some cases, the $\mathrm{pH}, \mathrm{EC}$ and element concentrations were unexpectedly higher in leachates where river water was used for irrigation before the simulated rainfall compared to irrigation with winery wastewater. It should be noted that $\mathrm{K}^{+}$and COD in the leachate from the Stellenbosch sand was substantially higher compared to the other soils, particularly where winery wastewater was applied (Table 8). Differences in the composition of the leachates clearly reflected in the different colors observed (Fig. 4). Winter rainfall following winery wastewater irrigation caused leaching of $\mathrm{K}^{+}$and $\mathrm{Na}^{+}$ from the soil, as explained earlier. The leachate from soils irrigated with winery wastewater were darker than those irrigated with river water, indicating leaching of organic matter. The color of the leachate from the Stellenbosch sand was similar to the winery wastewater applied (Fig. 4D). This indicated that substantial leaching of organic compounds applied via the winery wastewater occurred compared to the other soils.

\section{Amount of cations leached}

The amount of cations leached from the four soils where percolation occurred, were relatively low where river water, as well as diluted winery wastewater were applied. With the exception of $\mathrm{K}^{+}{ }_{\text {extr }}$, the amount of cations in the leachate declined non-linearly as the clay content increased (Fig. 5). Where river water was used for irrigation, the leached $\mathrm{K}^{+}{ }_{\text {extr }}$ was relatively high for the Stellenbosch sand, and low for the Rawsonville sand (Fig. 5A). In the case of the Stellenbosch sand, substantially more $\mathrm{K}^{+}$extr also leached where the wastewater was applied compared to the other soils (Fig. 5B). Perusal of the data revealed that the $\mathrm{K}_{\text {extr }}^{+}$

TABLE 8

Chemical composition of the leachate collected after simulated winter rainfall for soils that were first irrigated with river water (RW) and winery wastewater (WW), respectively. No leachate could be obtained for the Lutzville and Robertson soils. No statistical analysis was done on the leachate.

\begin{tabular}{|c|c|c|c|c|c|c|c|c|}
\hline \multirow{2}{*}{$\begin{array}{l}\text { Water quality } \\
\text { variable }\end{array}$} & \multicolumn{2}{|c|}{$\begin{array}{c}\text { Rawsonville } \\
\text { sand }\end{array}$} & \multicolumn{2}{|c|}{$\begin{array}{c}\text { Stellenbosch } \\
\text { shale }\end{array}$} & \multicolumn{2}{|c|}{$\begin{array}{c}\text { Stellenbosch } \\
\text { granite }\end{array}$} & \multicolumn{2}{|c|}{$\begin{array}{c}\text { Stellenbosch } \\
\text { sand }\end{array}$} \\
\hline & $\mathbf{R W}^{1}$ & $\mathbf{W W}^{2}$ & RW & WW & RW & WW & RW & WW \\
\hline $\mathrm{pH}$ & 7.1 & 7.5 & 6.7 & 6.5 & 6.3 & 6.5 & 6.1 & 7.2 \\
\hline $\mathrm{EC}^{1}(\mathrm{mS} / \mathrm{m})$ & 133.5 & 84.4 & 21.5 & 28.8 & 18 & 33.1 & 97.8 & 86.6 \\
\hline $\mathrm{Na}^{+}(\mathrm{mg} / \mathrm{L})$ & 58.8 & 53 & 17.2 & 25.8 & 15.9 & 31 & 54.3 & 73.5 \\
\hline $\mathrm{K}^{+}(\mathrm{mg} / \mathrm{L})$ & 16.1 & 81.3 & 6 & 24.6 & 7.6 & 52.4 & 147.7 & 242.3 \\
\hline $\mathrm{Ca}^{2+}(\mathrm{mg} / \mathrm{L})$ & 132.9 & 57.6 & 19.4 & 18.9 & 14.8 & 12.4 & 69.9 & 28.5 \\
\hline $\mathrm{Mg}^{2+}(\mathrm{mg} / \mathrm{L})$ & 87.3 & 33.9 & 7.2 & 7.5 & 5.8 & 6.3 & 23.8 & 11.8 \\
\hline $\mathrm{SAR}^{2}(\mathrm{mg} / \mathrm{L})$ & 0.06 & 0.06 & 0.17 & 0.17 & 0.2 & 0.2 & 0.92 & 0.25 \\
\hline $\mathrm{Fe}^{2+}(\mathrm{mg} / \mathrm{L})$ & 0.04 & 0.07 & 2.39 & 11.06 & 2.2 & 2.02 & 0.22 & 12.21 \\
\hline $\mathrm{P}(\mathrm{mg} / \mathrm{L})$ & 0.04 & 0.08 & 0.02 & 0.04 & 0.01 & 0.04 & 0.07 & 0.19 \\
\hline $\mathrm{NO}_{3}^{-}-\mathrm{N}$ & 0 & 0 & 0.07 & 0.04 & 0.05 & 0 & 0.15 & 0.08 \\
\hline $\mathrm{Cl}^{-}(\mathrm{mg} / \mathrm{L})$ & 185.8 & 106.2 & 31 & 53.1 & 35.4 & 57.5 & 92.9 & 119.4 \\
\hline $\mathrm{HCO}_{3}^{-}(\mathrm{mg} / \mathrm{L})$ & 53.6 & 145.5 & 15.3 & 7.7 & 7.7 & 23 & 7.7 & 183.7 \\
\hline $\mathrm{SO}_{4}^{2-}(\mathrm{mg} / \mathrm{L})$ & 95 & 65 & 17 & 32 & 18 & 35 & 61 & 82 \\
\hline $\mathrm{TDS}^{3}(\mathrm{mg} / \mathrm{L})$ & 0.04 & 0.06 & 0.02 & 0.03 & 0.02 & 0.03 & 0.03 & 0.08 \\
\hline $\mathrm{COD}^{4}(\mathrm{mg} / \mathrm{L})$ & 0.94 & 1.10 & 0.09 & 0.17 & 0.13 & 0.32 & 0.18 & 2.1 \\
\hline
\end{tabular}

\footnotetext{
${ }^{1}$ Electrical conductivity

${ }^{2}$ Sodium adsorption ratio

${ }^{3}$ Total dissolved solids

${ }^{4}$ Chemical oxygen demand
} 
variation seemed to be a function of (i) the initial $\mathrm{K}^{+}$in the soil before the irrigations were applied $\left(\mathrm{K}_{\text {initial }}\right)$ and (ii) the COD level in the leachate $\left(\mathrm{COD}_{\text {leachate }}\right)$. Based on this, c. $90 \%$ of the variation in leached $\mathrm{K}^{+}$could be explained by means of the following multiple linear regression equation.

$\mathrm{K}_{\text {leached }}=7.262 * \mathrm{~K}_{\text {initial }}+1.145 * \mathrm{COD}_{\text {leachate }}-1.58 \quad\left(\mathrm{R}^{2}=0.9279\right.$; s.e. $=0.42 ; \mathrm{p}=0.0006$ )

The high $\mathrm{K}^{+}$extr content in the Stellenbosch sand compared to the other soils probably contributed to the high level in the leachate. The higher COD in the leachate of the Stellenbosch sand suggested that the $\mathrm{K}^{+}$formed organic salts readily leached from the soil, particularly where the winery wastewater was applied prior to the simulated rainfall. These organic compounds probably contributed to the dark color of the leachate from the Stellenbosch sand (Fig. 4D). Surprisingly, the CEC did not make a significant contribution to the multiple linear regression model. However, the possibility that the relatively low CEC of the Stellenbosch
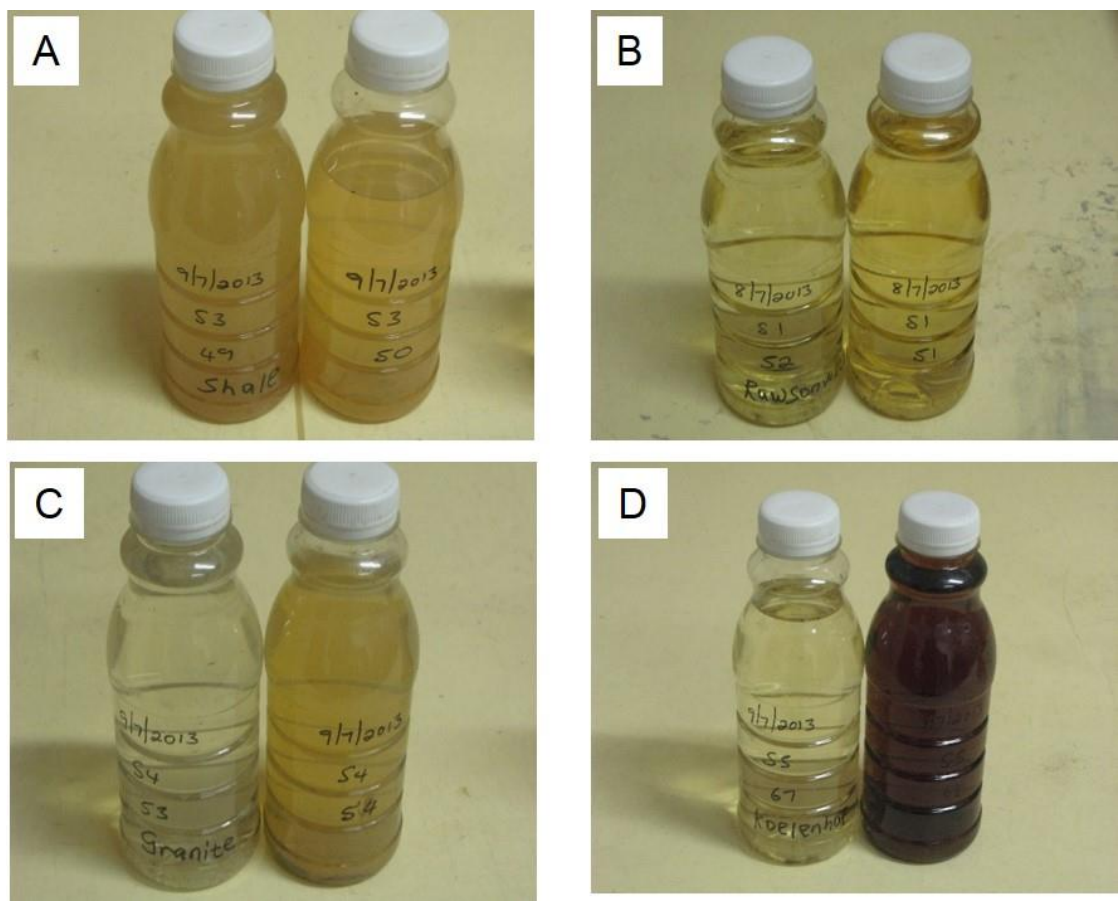

FIGURE 4

Examples of leachate collected after simulated winter rainfall from (A) Rawsonville sand, (B) Stellenbosch shale, (C) Stellenbosch granite and (D) Stellenbosch sand. Bottles on the left contains leachate where river water was applied.
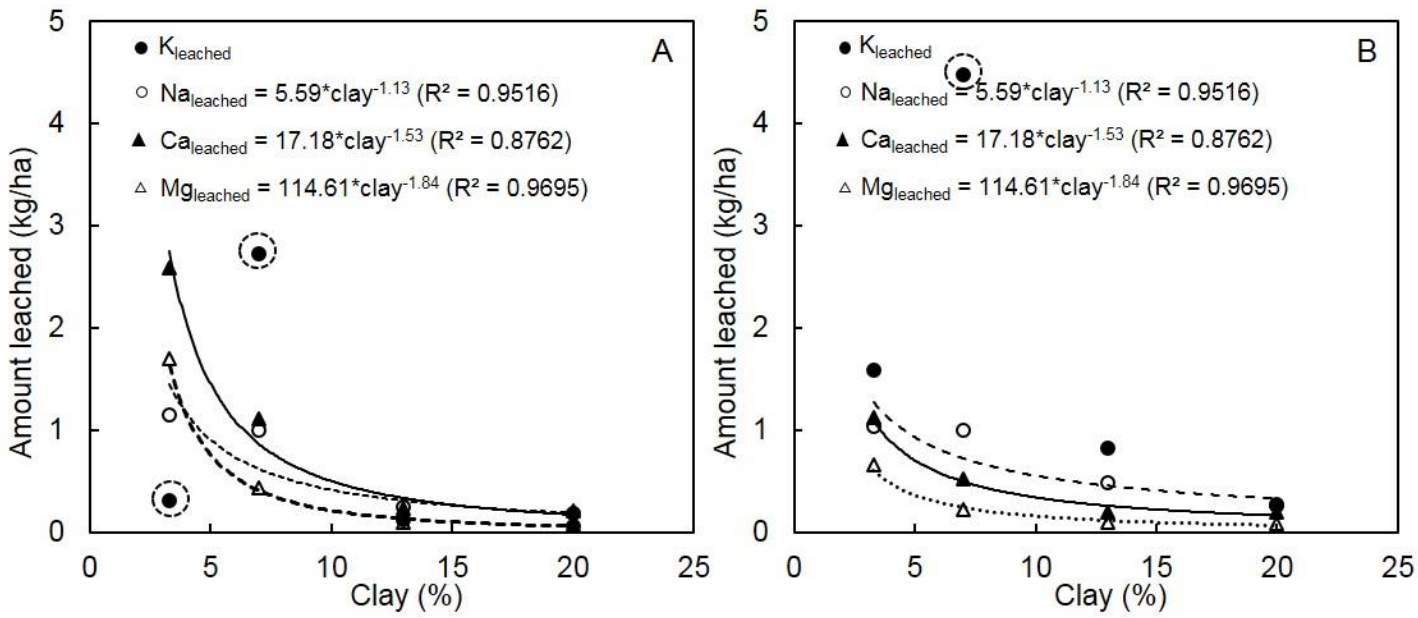

FIGURE 5

Relationship between the amount of basic cation leached and the clay content where simulated winter rainfall was applied to soils that were first irrigated with (A) river water and (B) diluted winery wastewater, respectively. Due to the encircled outliers, $\mathrm{K}^{+}$could not be related to the clay content. 
sand (Table 3) could have played a less prominent role was not ruled out.

\section{Soil chemical changes after irrigation and simulated winter rainfall \\ Basic cations}

Potassium: The soil $\mathrm{K}^{+}$, showed almost no change where river water was applied, irrespective of soil type (Fig. 6). In contrast, irrigation with winery wastewater increased the $\mathrm{K}_{\text {extr }}^{+}$in the six soils. Due to no, or limited leaching, as discussed above, the $\mathrm{K}^{+}$extr remained almost unchanged in all soils after the simulated winter rainfall. In fact, $\mathrm{K}_{\text {extr }}^{+}$in the Lutzville sand tended to increase slightly after the rainfall (Fig. 6B). The Stellenbosch sand was the only soil where the $\mathrm{K}^{+}$extr showed a prominent decline after the rainfall (Fig. 6E). This trend was probably due to the combined effect of the high initial $\mathrm{K}_{\text {extr }}^{+}$content and the organic compounds on the amount of $\mathrm{K}^{+}$leached from the soil, as discussed above. In spite of the leaching, the soil $\mathrm{K}^{+}$extr retained was still almost double the initial level.

Sodium: The $\mathrm{Na}^{+}$extr tended to increase in all soils where river water was used for irrigation (Fig. 7). This was due to the relatively high $\mathrm{Na}^{+}$content in the water (Table 6), i.e. on average $24.5 \mathrm{mg} / \mathrm{L}$ compared to $3.3 \mathrm{mg} / \mathrm{L}$ for $\mathrm{K}^{+}$. As expected, irrigation with the diluted winery wastewater increased the $\mathrm{Na}^{+}$extr in all soils to higher levels than river water irrigation in most of the soils (Fig. 6). The levels of $\mathrm{Na}^{+}$extr in the Lutzville sand and Robertson clay were similar after the river water, as well as winery wastewater irrigations (Figs. 7B \& 7F). At this stage, there is no explanation for this unexpected result, other than possible experimental errors. The $\mathrm{Na}^{+}$extr declined in all the soils where the simulated rainfall resulted in leaching (Fig. 7). Where river water was
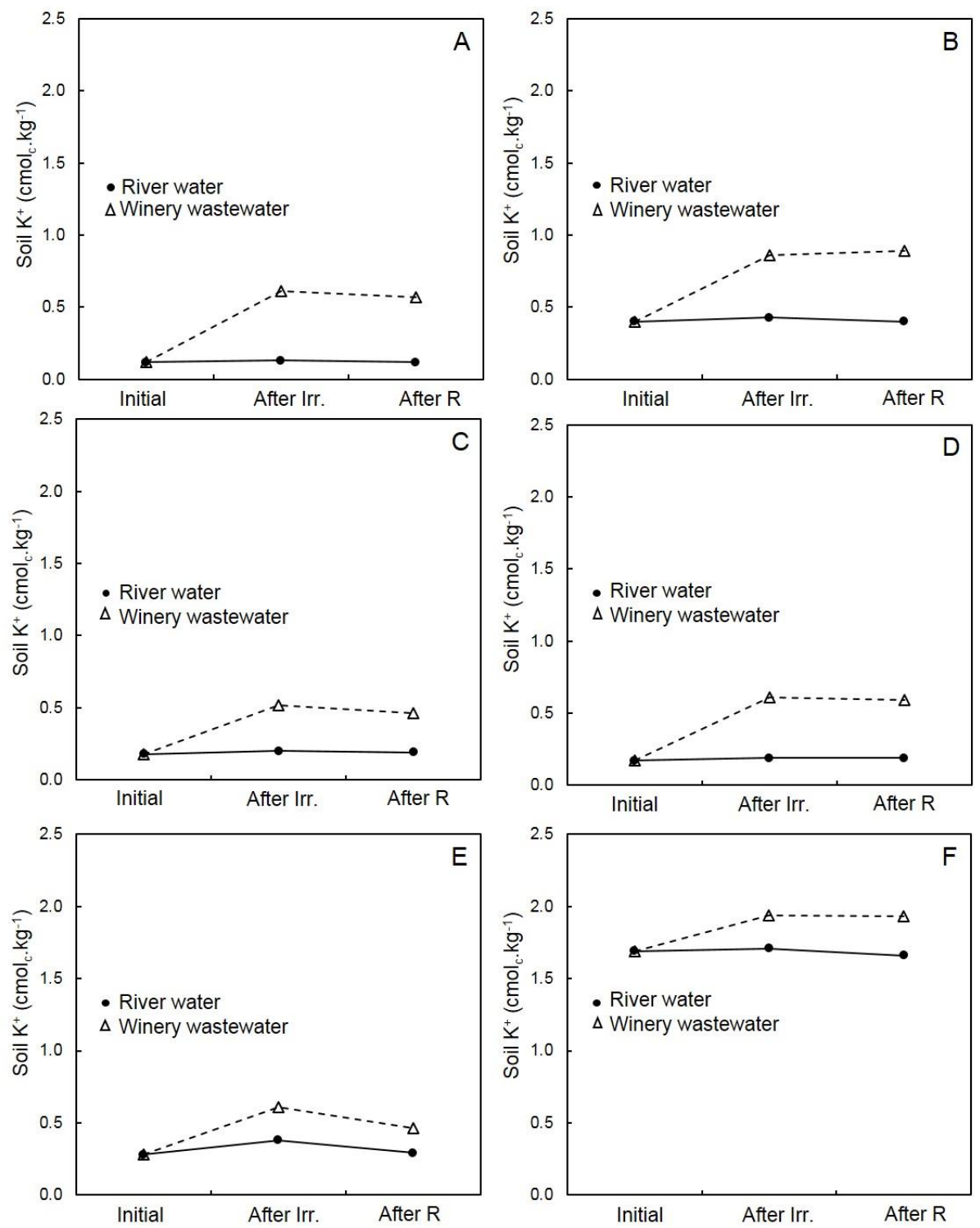

FIGURE 6

Effect of irrigation with river water and winery wastewater diluted to $3000 \mathrm{mg} / \mathrm{L} \mathrm{COD}$, (After Irr.) followed by simulated winter rainfall, (After R) on extractable soil $\mathrm{K}^{+}$for (A) Rawsonville sand, (B) Lutzville sand, (C) Stellenbosch shale, (D) Stellenbosch granite, (E) Stellenbosch sand and (F) Robertson clay. Samples from 3 replicates were pooled, hence no statistical analysis. 
used for irrigation, the $\mathrm{Na}^{+}$extr levels were comparable to the initial levels, or even lower in the Rawsonville sand, the initial levels. However, the simulated rainfall was insufficient to leach all the $\mathrm{Na}^{+}$where diluted winery wastewater was used for irrigation. Due to the relatively high $\mathrm{Na}^{+}$in the water used for the rainfall simulation (Fig. 2), the $\mathrm{Na}^{+}$extr in the Lutzville sand and Robertson clay increased after the rainfall simulation (Figs. 7B \& 7F). This indicated that the $\mathrm{Na}^{+}$in the river water used for the rainfall simulation contributed to the soil $\mathrm{Na}^{+}{ }_{\text {extr }}$ where diluted winery wastewater was applied.

Calcium: Although more $\mathrm{Ca}^{2+}$ was applied via the diluted winery wastewater (Table 7), it had no effect on the level of soil $\mathrm{Ca}^{2+}{ }_{\text {extr }}$ compared to the irrigation with river water, irrespective of soil type (Fig. 8). This indicated that the $c$. $35 \mathrm{mg} / \mathrm{L} \mathrm{Ca}^{2+}$ in the wastewater (Table 7) was too low to increase the soil $\mathrm{Ca}^{2+}$. Likewise, the simulated rainfall had no effect on the soil $\mathrm{Ca}^{2+}{ }_{\text {extr }}$, except for a substantial increase in the Robertson clay (Fig. 8F). At this stage, there is no explanation for this unexpected result.

Magnesium: Similar to $\mathrm{Ca}^{2+}{ }_{\text {extr }}$, irrigation with diluted winery wastewater had no effect on the level of soil $\mathrm{Mg}^{2+}{ }_{\text {ext }}$ compared to the irrigation with river water, irrespective of soil type (Fig. 9). The simulated rainfall had no effect on the $\mathrm{Mg}^{2+}{ }_{\text {extr }}$ in most soils. However, the $\mathrm{Mg}^{2+}$ extr increased in the Stellenbosch granite irrigated with winery wastewater before the rainfall simulation (Fig. 9D). The $\mathrm{Mg}^{2+}{ }_{\text {extr }}$ in the Robertson clay also increased after the simulated rainfall, irrespective of the water used for irrigation (Fig. 9F). At this stage, there is no explanation for these unexpected results.
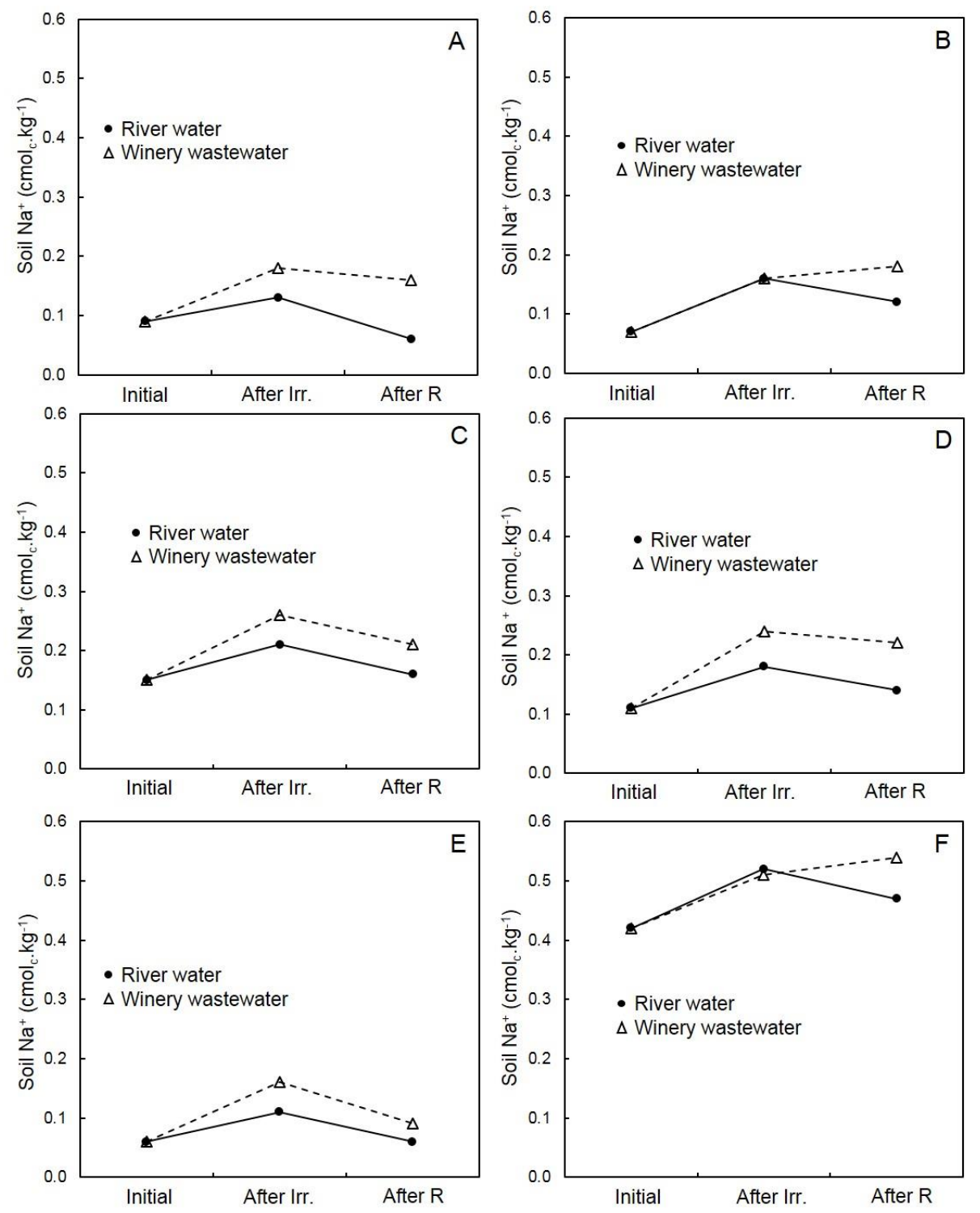

FIGURE 7

Effect of irrigation with river water and winery wastewater diluted to $3000 \mathrm{mg} / \mathrm{L} \mathrm{COD} \mathrm{(After} \mathrm{Irr.)} \mathrm{followed} \mathrm{by} \mathrm{simulated} \mathrm{winter}$ rainfall (After R) on extractable soil $\mathrm{Na}^{+}$for (A) Rawsonville sand, (B) Lutzville sand, (C) Stellenbosch shale, (D) Stellenbosch granite, (E) Stellenbosch sand and (F) Robertson clay. Samples from 3 replicates were pooled, hence no statistical analysis 

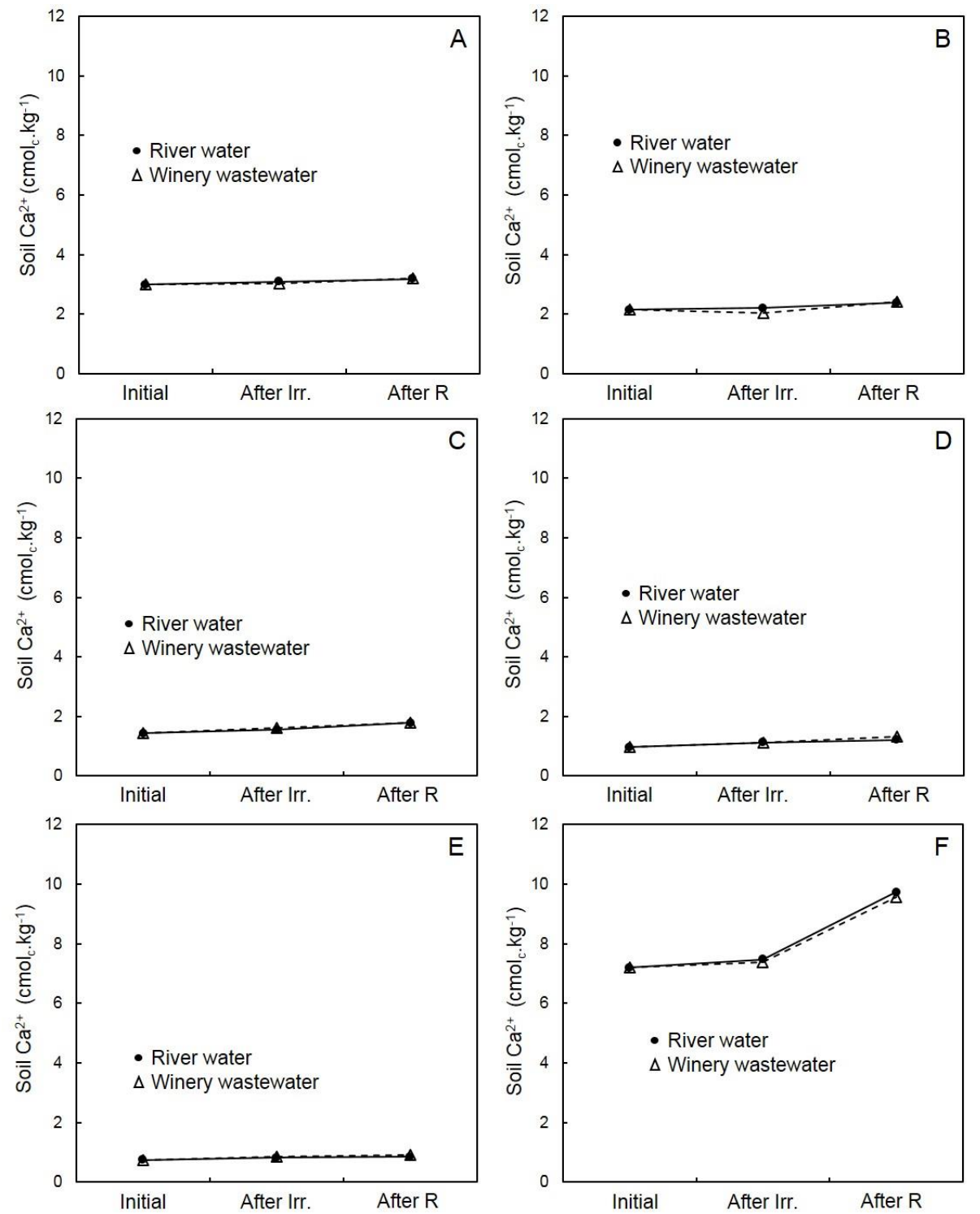

FIGURE 8

Effect of irrigation with river water and winery wastewater diluted to $3000 \mathrm{mg} / \mathrm{L} \mathrm{COD}$ (After Irr.) followed by simulated winter rainfall (After R) on extractable soil $\mathrm{Ca}^{2+}$ for (A) Rawsonville sand, (B) Lutzville sand, (C) Stellenbosch shale, (D) Stellenbosch granite, (E) Stellenbosch sand and (F) Robertson clay. Samples from 3 replicates were pooled, hence no statistical analysis.

\section{CONCLUSIONS}

Six different soils from three wine growing regions were subjected to simulated winter rainfall following one season of irrigation with winery wastewater. The winter rainfall could not leach basic cations, particularly $\mathrm{K}^{+}$and $\mathrm{Na}^{+}$, from two of the six soils as the amount of the simulated rainfall was too low to achieve leaching. Where three soils received the same amount of rainfall, more cations leached from the sandy soil compared to the two clayey soils. These trends indicated that the leaching would be a function of soil texture, as could be expected, as well as rainfall. The simulation with low rainfall events indicated that the basic cations are more likely to accumulate in soils if climate change results in lower winter rainfall in these regions.
Given the highly variable rainfall in South Africa, it is possible that abnormally high daily rainfall events can leach accumulated cations from vineyard soils in regions with relatively low average rainfall, especially in sandy soils. In regions where winter rainfall is not high enough to leach nutrients from the soil that was irrigated with winery wastewater, there is a potential for accumulation of high salt concentrations that will increase soil salinity. It can be recommended that if the Lutzville sand and Robertson clay soils are to be used for wastewater irrigation, proper management and monitoring of soils are essential to avoid accumulation of salts due to low winter rainfall in these regions. 

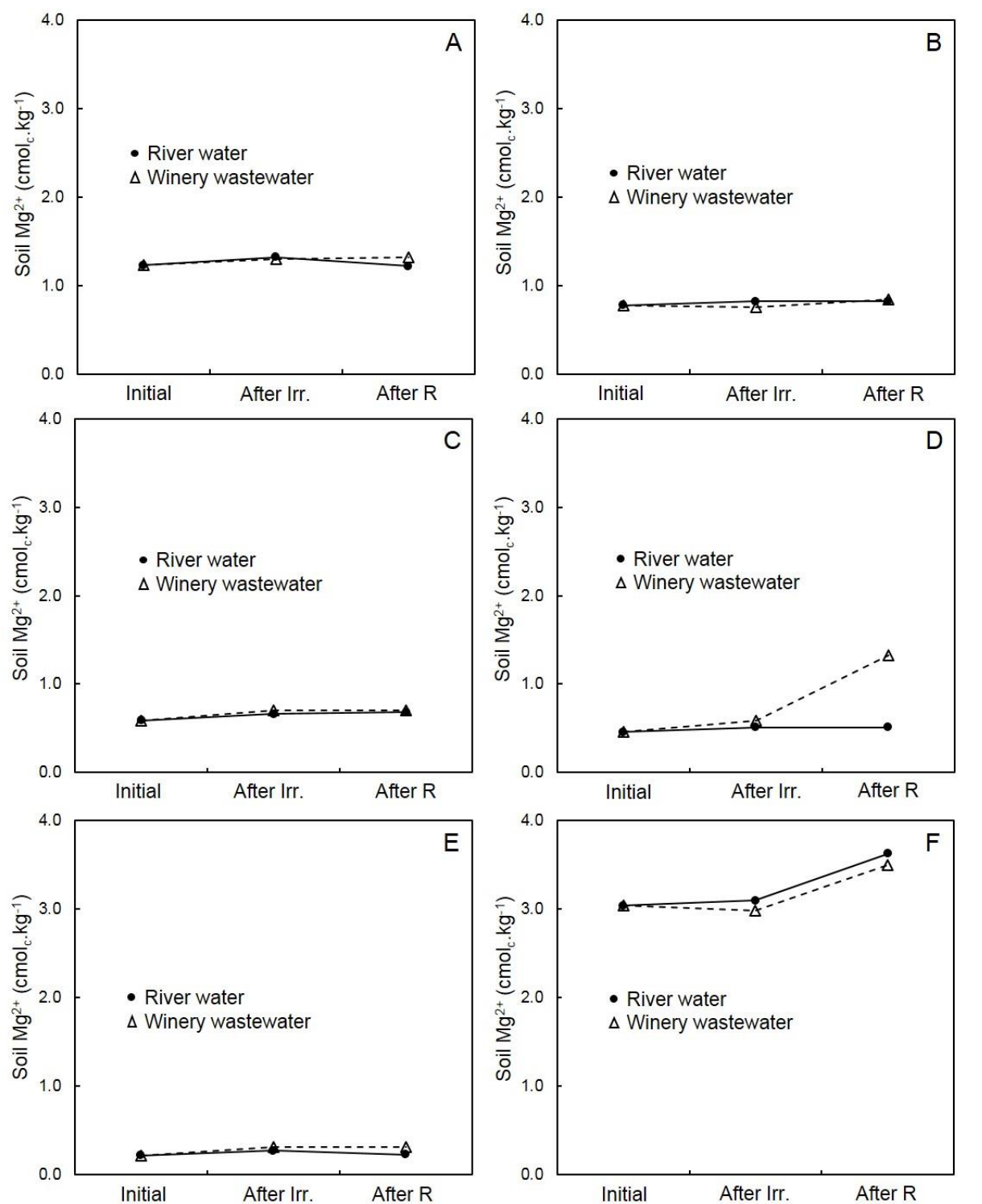

FIGURE 9

Effect of irrigation with river water and winery wastewater diluted to $3000 \mathrm{mg} / \mathrm{L} \mathrm{COD}$ (After Irr.) followed by simulated winter rainfall (After R) on extractable soil $\mathrm{Mg}^{2+}$ for (A) Rawsonville sand, (B) Lutzville sand, (C) Stellenbosch shale, (D) Stellenbosch granite, (E) Stellenbosch sand and (F) Robertson clay. Samples from 3 replicates were pooled, hence no statistical analysis.

\section{LITERATURE CITED}

Amezketa, E., Aragüés, R. \& Gazol R., 2004. Infiltration of water in disturbed soil columns as affected by clay dispersion and aggregate slaking. Sp. J. Agric. Res. 2, 459-471.

Department of Water Affairs \& Forestry, 1996. South African Water Quality Guidelines (second edition). Volume 1: Domestic Use. Department of Water Affairs \& Forestry, Private Bag X313, Pretoria, 0001.

Dobrowsky, P.H., 2014. Quality assessment of domestic harvested rainwater in the peri-urban region of Kleinmond, Western Cape and the optimisation of point-of-use treatment systems. Thesis, Stellenbosch University, Private Bag X1, Matieland 7602, South Africa.

Howell, C.L. \& Myburgh, P.A., 2018. Management of winery wastewater by re-using it for crop irrigation - A review. S. Afr. J. Enol. Vitic. 39, 116132.
Howell, C.L., Myburgh, P.A., Lategan, E.L. \& Hoffman, J.E., 2018. Effect of irrigation using diluted winery wastewater on the chemical status of a sandy alluvial soil, with particular reference to potassium and sodium. S. Afr. J. Enol. Vitic. 39, 284-296.

IUSS Working Group WRB., 2014. World Reference Base for Soil Resources. International classification system for naming soils and creating legends for soil maps. World Soil Resources Reports No. 106. FAO, Rome.

Mulidzi, A.R., Clarke, C.E. \& Myburgh, P.A., 2015. Effect of irrigation with diluted winery wastewater on cations and $\mathrm{pH}$ in four differently textured soils. S. Afr. J. Enol. Vitic. 36, 402-412.

Mulidzi, A.R., Clarke, C.E. \& Myburgh, P.A., 2016. Design of a pot experiment to study the effect of irrigation with diluted winery wastewater on four differently textured soils. Water SA 42, 20-25.

Mulidzi, A.R., Clarke, C.E. \& Myburgh, P.A., 2018. Annual dynamics of winery wastewater volumes and quality and the impact of disposal on poorly drained duplex soils. S. Afr. J. Enol. Vitic. 39, 305-314. 
Mulidzi, A.R., Clarke, C.E. \& Myburgh, P.A., 2019. Response of soil chemical properties to irrigation with winery wastewater on a well-drained sandy soil. S. Afr. J. Enol. Vitic. 40, 289-300.

Muller, K., Magesan, G.N. \& Bolan, N.S., 2007. Review: A critical review of the influence of effluent irrigation on the fate of pesticides in soil. Agr. Ecosyst. Environ. 120, 93-116.

Myburgh, P., 2012. Guidelines for vineyard irrigations with saline water. Wynboer Technical Yearbook 2012, 94-96.

Ott, R. L., 1998. An introduction to statistical methods and data analysis. Belmont, California, Duxbury Press, 807-837.

SAS, 2008. SAS Version 9.2., SAS Institute, Campus Drive, Cary, North Carolina 27513.

Shapiro, S.S. \& Wilk, M.B., 1965. An analysis of variance test for normality (complete samples). Biometrika 52, 591-611.
Soderberg, K., 2003. Geochemistry of the fynbos ecosystem in a Table Mountain Group sub-catchment of the Olifants River, Western Cape, South Africa. Thesis, Cape Town University, Private Bag X3, Rondebosch, 7701.

Soil Classification Work Group, 1991. Soil classification - A taxonomic system for South Africa. Memoirs on the Agricultural Natural Resources of South Africa no. 15. Dept. Agricultural Development, Pretoria, South Africa.

Suarez, D.L., Wood, J.D. \& Lesch, S.M., 2008. Infiltration into cropped soils: Effect of rain and sodium adsorption ratio-impacted irrigation water. J. Environ. Qual. 37, 169-179.

Vink, N., Deloire, A., Bonnardot, V. \& Ewert, J., 2012. Climate change and the future of South Africa's wine industry. American Association of Wine Economists105, 1-18. 